\title{
Penerapan Model Pembelajaran Webbed Dalam Meningkatkan Hasil Belajar Bahasa Indonesia Siswa Kelas III-C SD Negeri Beroanging Kota Makassar
}

\section{The Implementation of Webbed Learning Model to Improve the Indonesian Language Learning Outcomes for the Grade III-C Students at SD Negeri Beroanging, Makassar City}

\author{
A. Bunga Intang ${ }^{1 *}$, Andi Hamsiah ${ }^{2}$, Mas'ud Muhammadiah ${ }^{2}$ \\ ${ }^{1}$ Sekolah Dasar Negeri Beroangin Kota Makassar \\ ${ }^{2}$ Program Studi Pendidikan Dasar, Program Pascasarjana, Universitas Bosowa \\ *E-mail: a.bungaintang@gmail.com
}

Diterima: 15 September 2021/Disetujui 20 Desember 2021

\begin{abstract}
Abstrak. Tujuan yang ingin dicapai dalam penelitin ini adalah (1) mendeskripsikan penerapan model pembelajaran webbed dapat meningkatkan motivasi dan aktivitas belajar bahasa Indonesia siswa kelas III-C SD Negeri Beroanging Kota Makassar; (2) mendeskripsikan penerapan model pembelajaran webbed dapat meningkatkan hasil belajar bahasa Indonesia siswa kelas III-C SD Negeri Beroanging Kota Makassar, khususnya membaca. Jenis penelitian yang digunakan adalah penelitian tindakan kelas (PTK) dengan menggunakan desain penelitian PTK, yang meliputi: perencanaan tindakan, pelaksanaan tindakan, observasi dan evaluasi, serta refleksi. Hasil penelitian ini menyimpulkan bahwa (1) penerapan model pembelajaran webbed dalam pembelajaran bahasa Indonesia pada siswa kelas III-C SD Negeri Beroanging Kecamatan Tallo Kota Makassar dapat meningkatkan motivasi dan aktivitas belajar bahasa Indonesia. Hal ini ditunjukkan oleh respon siswa yang pada umumnya menyatakan respon yang positif (setuju dan sangat setuju) terhadap 10 butir pertanyaan/pernyataan angket, serta tidak ada satu pun respon siswa yang menyatakan respon negatif (tidak setuju dan sangat tidak setuju) terhadap pertanyaan/pernyataan angket tersebut yang berkaitan dengan motivasi dan aktivitas belajar siswa; dan (2) penerapan model pembelajaran webbed dalam pembelajaran bahasa Indonesia siswa kelas III-C SD Negeri Beroanging Kecamatan Tallo Kota Makassar dapat meningkatkan hasil belajar bahasa Indonesia, khususnya membaca. Hal ini ditunjukkan oleh peningkatan hasil belajar siswa pada siklus I yakni perolehan nilai hasil belajar baru mencapai $55 \%$ yang mencapai ketuntasan belajar berdasarkan KKM, kemudian mengalami peningkatan nilai menjadi $100 \%$ pada siklus II.
\end{abstract}

Kata Kunci: Penerapan, Model Pembelajaran Webbed, Kriteria Ketuntasan Minimal (KKM), Motivasi Dan Aktivitas Belajar, Siklus.

\begin{abstract}
The objectives that will be achieved in this research are: (1) to describe the application of the webbed learning model that can improve the motivation and activities in learning Indonesian language for the grade III-C students at SD Negeri Beroanging Makassar City; (2) to describe the application of the webbed learning model that can improve the Indonesian language learning outcomes of the grade III-C students at SD Negeri Beroanging Makassar City, especially in reading. The type of this research was classroom action research (CAR). Classroom action research (CAR) includes: planning action, action implementation, observation and evaluation, and reflection. The results of this research concludes that: (1) the application of the webbed learning model in Indonesian language learning at the grade III-C students at SD Negeri Beroanging, Tallo District, Makassar City can improve students' motivation and Indonesian language learning activities. This can be seen from the students' responses which generally stated positive responses (agree and strongly agree) to the 10 questions/questionnaire statements, and none of the students' responses expressed negative responses (disagree and strongly disagree) to the questions/statements. The questionnaire was related to the students' motivation and learning activities; and (2) the application of the webbed learning model in learning Indonesian language at the grade III-C students at SD Negeri Beroanging, Tallo District, Makassar City can improve Indonesian language learning outcomes, especially reading. This can be seen from the improvement of students' learning outcomes in the first cycle, namely the acquisition of new learning outcomes reaching 55\% which achieved learning mastery based on the KKM, then it improved the value to $100 \%$ in the second cycle.
\end{abstract}

Keywords: The Application, Webbed Learning Model, Completeness Criteria Minimum (KKM), Motivation And Learning Activities, Cycles.

This work is licensed under Creative Commons Attribution License 4.0 CC-BY International license

\section{Pendahuluan}

Proses pembelajaran merupakan suatu wadah yang di dalamnya terdapat kegiatan guru dan siswa, yang saling mendukung untuk terciptanya sebuah tujuan. Kegiatan mengajar yang dilakukan oleh guru dan kegiatan belajar yang 
dilakukan oleh siswa memengaruhi satu sama lain dalam memperlancar berlangsungya proses pembelajaran. Dalam memahami kegiatan yang dilakukan oleh guru dan siswa selama proses pembelajaran, maka perlu memahami beberapa pandangan mengenai belajar dan pembelajaran.

Pandangan mengenai belajar telah banyak mengalami perubahan seiring dengan perkembangan pengetahuan. Oleh karena itu, terdapat pandangan tradisional dan pandangan modern mengenai makna belajar. Pandangan trasidional mengenai belajar lebih mengarah pada pengembangan intelektualitas atau pengembangan otak (kecerdasan), sehingga belajar lebih pada usaha memperoleh sejumlah ilmu pengetahuan. Makna belajar berdasarkan pandangan tradisional ini memiliki arti bahwa ilnu pengetahuan yang diperoleh dari bacaan menjadi kekuatan dalam mendapatkan kekuasaan. Dengan demikian, proses belajar menitikberatkan pada ilmu pengetahuan (Isro'atun \& Rosmala, 2018).

Pendidikan adalah sebuah proses transformasi ilmu pengetahuan dari satu generasi ke generasi berikutnya. Proses penyampaian itu meliputi proses sosialisasi dan proses pembiasaan (pembudayaan). Oleh karena itu, perubahan atau perkembangan pendidikan merupakan hal yang harus terjadi seiring dengan perubahan budaya kehidupan. Sejalan dengan hal itu, dalam Undang-Undang Nomor 20 Tahun 2003 tentang Sistem Pendidikan Nasional disebutkan bahwa pendidikan nasional berfungsi mengembangkan kemampuan dan membentuk watak serta peradaban bangsa yang bermartabat dalam rangka mencerdaskan kehidupan bangsa. Pendidikan bertujuan untuk mengembangkan potensi peserta didik agar menjadi manusia yang beriman dan bertakwa kepada Tuhan Yang Maha Esa, berakhlak mulia, sehat, berilmu, cakap, kreatif, mandiri, dan menjadi warga negara yang demokratis, serta bertanggung jawab.

Salah satu model pembelajaran yang dapat digunakan dan dianggap cocok dalam pembelajaran bahasa Indonesia di sekolah dasar (SD) untuk meningkatkan hasil belajar siswa adalah model pembelajaran terpadu webbed. Hal ini didukung oleh hasil pengkajian Tim Pengembang PGSD, sebagaimana dikemukakan oleh Hernawan dan Rosmini (2017) bahwa terdapat tiga model pembelajaran terpadu yang dianggap paling cocok atau tepat diterapkan di sekolah dasar (SD), yaitu model jaring laba-laba (webbed), model keterhubungan (connected), dan model keterpaduan (integrated).

Istilah pembelajaran terpadu terdiri dari dua kata, yaitu pembelajaran dan terpadu. Pembelajaran merupakan terjemahan dari instructional, yang berarti proses memberi ransangan kepada siswa supaya belajar. Pembelajaran berbeda dengan pengajaran yang merupakan terjemahan dari teaching. Pada proses pembelajaran biasanya ada guru yang mengajar siswa, sedangkan dalam proses pembelajaran tidak selalu demikian (Santoso, dkk. 2017).

Widoyoko (2019) mengemukakan bahwa pembelajaran merupakan salah satu bemtuk program, sehingga pembelajaran yang baik memerlukan perencanaan yang matang dan dalam pelaksanaannya melibatkan berbagai orang, baik guru maupun siswa, memiliki keterkaitan antara kegiatan pembelajaran yang satu dengan kegiatan pembelajaran yang lain untuk mencapai kompetensi bidang studi yang pada akhirnya untuk mendukung pencapaian kompetensi lulusan, serta berlangsung dalam suatu organisasi.

Menurut Ghazali (2015) bahwa pembelajaran dalam kelas merupakan peristiwa yang berbeda-beda jenisnya. Di antaranya, berupa unit rangkaikan kurikulukum yang terencana dan berurutan Berdasarkan pola-pola pembelajaran tersebut di atas, maka membelajarkan itu tidak hanya sekadar mengajar (seperti pola satu), karena membelajarkan yang berhasil harus memberikan banyak perlakuan kepada siswa. Peran guru dalam pembelajaran lebih dari sekadar sebagai informator belaka, akan tetapi guru harus memiliki multi peran dalam pembelajaran. Pola pembelajaran yang diterapkan oleh guru harus bervariasi, maka bahan pembelajarannya harus dipersiapkan secara bervariasi juga.

Aminuddin (dalam Hernawan dan Rosmini, 2017) memberikan batasan atau definisini pembelajaran terpadu sebagai berikut:

a. Suatu pendekatan pembelajaran yang menghubungkan berbagai mata pelajaran yang mencerminkan dunia nyata di sekeliling sertadalam rentang kemampuan dan perkembangan anak.

b. Suatu cara untuk mengembangkan pengetahuan dan keterampilan anak secara serempak (simultan).

c. Pembelajaran yang merakit atau menggabungkan sejumlah konsep dalam beberapa mata pelajaran yang berbeda, dengan harapan siswa akan belajar dengan lebih baik dan bermakna.

Pembelajaran terpadu merupakan suatu pendekatan yang berorientasi pada praktekpembelajaran yang sesuai dengan kebutuhan perkembangan anak. Pendekatan ini berangkat dari teori pembelajaran yang menolak proses latihan/hafalan (drill) sebagai dasar pembentukan pengetahuan dan struktur intelektual anak. Teori pembelajaran ini dimotori para tokoh Psikologi Gestalt, (termasuk teori Piaget) yang menekankan bahwa pembelajaran itu haruslah bermakna dan menekankan juga pentingnya program pembelajaran yang berorientasi pada kebutuhan perkembangan anak (Hernawan dan Rosmini, 2017)

Pelaksanaan pendekatan pembelajaran terpadu ini bertolak dari suatu topik atau tema yang dipilih dan dikembangkan oleh guru bersama-sama dengan anak. Tujuan dari tema ini bukan hanya untuk menguasai konsep-konsepmata pelajaran, akan tetapi konsep-konsep dari mata pelajaran terkait dijadikan sebagai alat dan wahana untuk mempelajari dan menjelajahi topik atau tema tersebut. Jika dibandingkan dengan pendekatan konvensional, maka pembelajaran terpadu tampaknya lebih menekankan pada keterlibatan anak dalam proses belajar atau mengarahkan anak secara aktif terlibat dalam proses pembelajaran dan pembuatan keputusan. Pendekatan pembelajaran terpadu ini lebih menekankan pada penerapan konsep belajar sambil melakukan sesuatu (learning by doing).

Penerapan pembelajaran terpadu di sekolah dasar bisa dikatakan sebagai suatu upaya untuk memperbaiki kualitas pendidikan, terutama dalam rangka mengimbangi gejala penjejalan isi kurikulum yang sering terjadi dalam proses pembelajaran yang dilaksanakan di sekolah-sekolah. Penjejalan isi kurikulum tersebut dikhawatirkan akan mengganggu perkembangan anak, karena terlalu banyak menuntut anak untuk mengerjakan aktivitas atau tugas-tugas yang melebihi kapasitas dan kebutuhan mereka. Dengan demikian, anak kehilangan sesuatu yang seharusnya bisa mereka kerjakan. Jika dalam proses pembelajaran, anak hanya merespon segalanya dari guru, maka mereka akan kehilangan pengalaman pembelajaran yang alamiah dan langsung (direct experiences). Pengalaman-pengalaman sensorik yang membentuk dasar 
kemampuan pembelajaran abstrak siswa menjadi tidak tersentuh, hal tersebut merupakan karakteristik utama perkembangan anak usia sekolah dasar.

\section{Metode Penelitian}

Jenis penelitian yang digunakan dalam penelitian ini adalah penelitian tindakan kelas (PTK) dengan menggunakan desain penelitian PTK, yang meliputi: perencanaan tindakan, pelaksanaan tindakan, observasi dan evaluasi, serta refleksi. Untuk menghindari terjadinya persepsi yang berbeda mengenai istilah yang digunakan dalam penelitian ini, maka perlu diberikan defenisi atau batasan istilah dalam penelitian ini. Secara singkat definisi istilah akan diuraikan di bawah ini.

1. Model pembelajaran webbed adalah model pembelajaran terpadu yang menggunakan pendekatan tematik dengan model pengembangan dimulai dari menentukan tema tertentu yang ditetapkan dengan cara negoisasi siswa atau dapat pula dengan cara berdiskusi bersama antara guru dan siswa. Setelah tema disepakati, kemudian dikembangkan menjadi subtema-subtema dengan memperhatikan kaitannya dengan bidang studi, kemudian dikembangkan aktivitas belajar yang harus dilakukan oleh siswa.

2. Motivasi yang dimaksudkan dalam penelitian ini adalah gairah belajar dari siswa yang ditunjukkan melalui aktivitas belajarnya yang penuh semangat, yang dapat diketahui melalui observasi, apakah semangat atau motivasi belajar siswa dapat mengalami peningkatan setelah diterapkannya model pembelajaran webbed.

3. Aktivitas belajar yang dimaksud dalam penelitian ini adalah kegiatan yang melibatkan siswa dalam proses pembelajaran dengan memperhatikan tingkat partisipasi siswa (keaktifan dalam belajar), apakah mengalami peningkatan aktvitas dalam belajar, seperti aktif dalam mengikuti proses pembelajaran, rajin bertanya, dan antusias dalam menjawab pertanyaan setelah diterapkannya model pembelajaran webbed.

4. Hasil belajar yang dimaksudkan dalam penelitian ini adalah hasil yang diperoleh siswa setelah mengikuti proses pembelajaran, berupa nilai atau angka sebagai bentuk prestasi belajar, apakah siswa memperoleh nilai yang baik atau buruk setelah diterapkannya model pembelajaran webbed. Apabila siswa pada umumnya memperoleh nilai baik, maka hasil belajar siswa tersebut dianggap baik pula.

Fokus penelitian adalah titik pusat yang menjadi objek penelitian yang akan menjadi sasaran dalam sebuah penelitian. Karena peneltian ini menggunakan penelitian tindakan kelas (PTK), maka yang menjadi fokus dalam penelitian ini adalah keseluruhan siswa kelas III SD Negeri Beroanging Kota Makassar yang berjumlah 20 orang siswa.

\section{Hasil dan Pembahasan}

\section{A. Penyajian Hasil Penelitian}

Pada bagian ini akan disajikan dua pembahasan pokok sebagai upaya untuk menjawab pertanyaan yang telah dikemukakan pada bagian rumusan masalah. Permasalahan itu akan diuraikan pada bagian penyajian hasil penelitian ini dengan mengacu pada dua hal pokok, yang meliputi: (1) deskripsi penerapan model pembelajaran webbed dalam meningkatkan motivasi dan aktivitas belajar bahasa Indonesia siswa kelas III-C SD Negeri Beroanging Kecamatan Tallo Kota Makassa; dan (2) deskripsi penerapan model pembelajaran webbed dapat meningkatkan hasil belajar bahasa Indonesia siswa kelas III-C SD Negeri Beroanging Kota Makassar?

Untuk mendeskripsikan motovasi belajar Bahasa Indonesia, khususnya memaba siswa kelas III-C SD Negeri Beroanging Kecamatan Tallo Kota Makassar dengan menggunakan model pembelajaran webbed, maka digunakanlah angket yang kemudian dijawab oleh responden sebanyak 20 orang siswa. Ada 10 butir pertanyaan angket yang akan dijawab oleh responden (Agus, 2015), yaitu (1) apakah materi yang diajarkan oleh guru bahasa Indonesia bermanfaat bagi Anda?; (2) apakah Anda tidak termotivasi mengikuti mata pelajaran Bahasa Indonesia?; (3) apakah penjelasan guru Bahasa Indonesia mendorong Anda untuk bersemangat (termotivasi) dan beraktivitas secara aktif dalam belajar?; (4) apakah dalam pembelajaran Bahasa Indonesia, guru sering melakukan tanya jawab untuk meningkatkan aktivitas dan hasil belajar Anda dalam pembelajaran Bahasa Indonesia, khususnya membaca?; (5) apakah Anda setuju bahwa guru bahasa Indonesia dalam memberikan penjelasan materi, seringkali kurang jelas atau tidak dapat dipahami, sehingga tidak dapat meningkatkan aktivitas dan hasil belajar Anda, khususnya membaca? (6) apakah dalam pembelajaran Bahasa Indonesia sering dikaitkan dengan pembelajaran yang lain?; (7). apakah Anda setuju bahwa penggunaan model pembelajaran webbed tidak membangkitkan motivasi dan aktivitas Anda dalam berdiskusi atau mengemukakan pendapat, sehingga tidak dapat meningkatkan hasil belajaranya, khususnya membaca?; (8) apakah Anda setuju bahwa penggunaan model pembelajaran webbed dapat membangkitkan aktivitas dan motivasi Anda untuk memperluas pemahaman Anda terhadap materi yang disampaikan oleh guru, sehingga mempengaruhi hasil belajarnya?; (9) apakah Anda setuju bahwa setelah diterapkannya model pembelajaran webbed, Anda mempunyai aktivitas yang sangat aktif dan mempengaruhi hasil belajar bahasa Indonesia, khususnya membaca?; (10) apakah Anda setuju bahwa penggunaan model pembelajaran webbed dapat membangkitkan motivasi dan aktivitas Anda dalam mengerjakan tugas atau PR?.

Tabel 1 Respon Siswa Mengenai Motivasi dan Aktivitas Belajar dengan Menggunakan Model Pembelajaran Webbed

\section{Respon Siswa}




\begin{tabular}{|c|c|c|c|c|c|c|c|c|c|}
\hline \multirow[t]{2}{*}{ No } & \multirow[t]{2}{*}{ Pertanyaan } & \multicolumn{2}{|c|}{$\begin{array}{l}\text { Sangat } \\
\text { Setuju }\end{array}$} & \multicolumn{2}{|c|}{ Setuju } & \multicolumn{2}{|c|}{$\begin{array}{l}\text { Tidak } \\
\text { Setuju } \\
\end{array}$} & \multicolumn{2}{|c|}{$\begin{array}{l}\text { Sangat Tidak } \\
\text { Setuju }\end{array}$} \\
\hline & & $\mathrm{F}$ & $\%$ & $\mathrm{~F}$ & $\%$ & $\mathrm{~F}$ & $\%$ & $\mathrm{~F}$ & $\%$ \\
\hline 1. & $\begin{array}{l}\text { Apakah materi yang diajarkan } \\
\text { oleh guru bahasa Indonesia } \\
\text { bermanfaat bagi Anda? }\end{array}$ & 13 & 65 & 7 & 35 & - & - & - & - \\
\hline 2. & $\begin{array}{l}\text { Apakah Anda tidak } \\
\text { termotivasi mengikuti mata } \\
\text { pelajaran bahasa Indonesia? } \\
\text { Apakah penjelasan guru } \\
\text { bahasa Indonesia mendo-rong }\end{array}$ & - & - & - & - & 8 & 40 & $12-$ & 60 \\
\hline 3. & $\begin{array}{l}\text { Anda untuk berse-mangat } \\
\text { (termotivasi) dan beraktivitas } \\
\text { secara aktif dalam belajar? }\end{array}$ & 11 & 55 & 9 & 45 & - & & - & \\
\hline 4. & $\begin{array}{l}\text { Apakah dalam pembel-ajaran } \\
\text { bahasa Indonesia, guru sering } \\
\text { melakukan tanya jawab untuk } \\
\text { meningkatkan aktivitas dan } \\
\text { hasil belajar Anda dalam } \\
\text { pembelajaran } \\
\text { Indonesia, baha-sa } \\
\text { membaca? }\end{array}$ & 12 & 60 & 8 & 40 & & & & \\
\hline 5. & $\begin{array}{l}\text { Apakah Anda setuju bahwa } \\
\text { guru bahasa Indo-nesia dalam } \\
\text { memberikan penjelasan } \\
\text { materi, sering-kali kurang } \\
\text { jelas atau tidak dapat } \\
\text { dipahami, sehingga tidak } \\
\text { dapat meningkatkan aktivitas } \\
\text { dan hasil belajar Anda, } \\
\text { khususnya mem-baca? }\end{array}$ & 11 & 55 & 9 & 45 & 9 & 45 & 11 & 55 \\
\hline 6. & $\begin{array}{l}\text { Apakah dalam pembel-ajaran } \\
\text { bahasa Indonesia sering } \\
\text { dikaitkan dengan } \\
\text { pembelajaran yang lain? }\end{array}$ & 11 & 55 & 9 & 45 & & & & \\
\hline 7. & $\begin{array}{l}\text { Apakah Anda setuju bahwa } \\
\text { penggunaan model } \\
\text { pembelajaran webbed tidak } \\
\text { membangkitkan motivasi dan } \\
\text { aktivitas Anda dalam } \\
\text { berdiskusi atau mengemu- } \\
\text { kakan pendapat, sehingga } \\
\text { tidak dapat meningkatkan } \\
\text { hasil belajaranya, khusus-nya } \\
\text { membaca? }\end{array}$ & - & - & - & - & 10 & 50 & 10 & 50 \\
\hline 8. & $\begin{array}{l}\text { Apakah Anda setuju bah-wa } \\
\text { penggunaan model } \\
\text { pembelajaran webbed dapat } \\
\text { membangkitkan akti-vitas dan } \\
\text { motivasi Anda untuk } \\
\text { memperluas pema-haman } \\
\text { Anda terhadap materi yang } \\
\text { disampaikan oleh guru, } \\
\text { sehingga mem-pengaruhi } \\
\text { hasil belajar-nya, khususnya } \\
\text { membaca? }\end{array}$ & 11 & 55 & 9 & 45 & & & & \\
\hline 9. & $\begin{array}{l}\text { Apakah Anda setuju bah-wa } \\
\text { setelah diterapkannya model } \\
\text { pembelajaran webbed, Anda } \\
\text { mempunyai aktivitas yang } \\
\text { sangat aktif dan } \\
\text { mempengaruhi hasil belajar } \\
\text { bahasa Indonesia, khususnya } \\
\text { membaca? }\end{array}$ & 8 & 40 & 12 & 60 & & & & \\
\hline 10. & $\begin{array}{l}\text { Apakah Anda setuju bah-wa } \\
\text { penggunaan model } \\
\text { pembelajaran webbed da-pat } \\
\text { membangkitkan moti-vasi dan } \\
\text { aktivitas Anda dalam } \\
\text { mengerjakan tugas atau PR? }\end{array}$ & 16 & 80 & 4 & 20 & & & & \\
\hline
\end{tabular}


Berdasarkan Tabel 1 di atas, dapat digambarkan bahwa pada umumnya responden memilih alternatif jawaban sangat setuju dan setuju, sehingga tidak ada satu pun responden yang memilih tidak setuju dan sangat tidak setuju. Untuk lebih jelasnya, maka butir pertanyaan akan dianalisis satu per satu. Berdasarkan hasil analisis butir pertama pertanyaan angket dapat digambarkan, yaitu terdapat 13 responden (65\%) yang menyatakan sangat sangat setuju bahwa materi yang diajarkan oleh guru bahasa Indonesia bermanfaat bagi siswa, 7 orang responden (35\%) yang menyatakan setuju, dan tidak ada satu pun yang menyatakan tidak setuju dan sangat tidak setuju. Hal ini menunjukkan bahwa materi yang disajikan oleh guru Bahasa Indonesia bermanfaat bagis siswa. Dengan demikian, dapat dikatakan bahwa penggunaan model pembelajaran webbed dapat membangkitkan motivasi belajar siswa, sehingga diharapkan dapat, meningkatkan hasil belajar siswa.

Hasil analisis butir pertanyaan angket keempat memperlihatkan bahwa terdapat 12 responden (60\%) yang menyatakan sangat setuju guru dalam pembelajaran Bahasa Indonesia melakukan tanya jawab untuk meningkatkan aktivitas dan hasil belajar siswa dalam pembelajaran Bahasa Indonesia, khususnya membaca. Terdapat 8 responden (40\%) yang menyatakan setuju dan tidak ada satu pun yang menyatakan tidak setuju guru dalam pembelajaran bahasa Indonesia tidak melakukan tanya jawab untuk meningkatkan aktivitas dan hasil belajar siswa dalam pembelajaran Bahasa Indonesia, khususnya membaca. Demikian pula, tidak ada pun responden yang menyatakan sangat tidak setuju bahwa guru tidak menggunakan tanya jawab dalam pembelajaran, sehingga tidak meningkatkan aktivitas dan hasil belajar siswa, khususnya membaca. Dengan demikian, dapat dikatakan bahwa pembelajaran Bahasa Indonesia yang dilakukan oleh guru dengan menggunakan metode tanya jawab dapat meningkatkan aktivitas dan hasil belajar siswa.

Hasil anailisis pertanyaan angket kelima menunjukkan bahwa terdapat 11 responden (55\%) yang menyatakan sangat tidak setuju bahwa guru Bahasa Indonesia dalam memberikan penjelasan materi, seringkali kurang jelas atau tidak dapat dipahami, sehingga tidak dapat meningkatkan aktivitas dan hasil belajar siswa, khususnya. Terdapat 9 responden (45\%) yang menyatakan tidak setuju bahwa guru Bahasa Indonesia dalam memberikan penjelasan materi, seringkali kurang jelas atau tidak dapat dipahami, sehingga tidak dapat meningkatkan aktivitas dan hasil belajar. Sebaliknya, tidak ada satu pun respon yang menyatakan setuju dan sangat setuju bahwa guru Bahasa Indonesia dalam memberikan penjelasan materi, seringkali kurang jelas atau tidak dapat dipahami, sehingga tidak dapat meningkatkan aktivitas dan hasil belajar siswa. Dengan demikian, dapat dinyatakan bahwa penjelasan materi yang dilakukan oleh guru Bahasa Indonesia dalam sangat jelas, sehingga berimplikasi pada peningkatan aktivitas dan hasil belajar siswa.

Tabel 2 Nilai Hasil Tes Membaca Bahasa Indonesia dengan Menggunakan Model Pembelajaran Webbed

\begin{tabular}{|c|c|c|c|c|c|}
\hline \multirow{2}{*}{\multicolumn{2}{|c|}{ No. }} & \multirow{2}{*}{ Kode Subjek } & \multicolumn{2}{|c|}{ Hasil Tes per Siklus } & \multirow{2}{*}{ Keterangan } \\
\hline & & & Siklus 1 & Siklus 2 & \\
\hline 1. & NS & & 79 & 82 & \multirow{20}{*}{$\begin{array}{c}\text { Secara umum } \\
\text { mengalami peningkatan } \\
\text { nilai hasil tes belajar } \\
\text { dari siklus perta-ma ke } \\
\text { siklus kedua. }\end{array}$} \\
\hline 2. & $\mathrm{RH}$ & & 80 & 86 & \\
\hline 3. & SAD & & 79 & 84 & \\
\hline 4. & MHBS & & 80 & 84 & \\
\hline 5. & RY & & 80 & 83 & \\
\hline 6. & SMA & & 82 & 85 & \\
\hline 7. & AS & & 80 & 87 & \\
\hline .8 & ZAP & & 80 & 85 & \\
\hline 9. & MIN & & 81 & 87 & \\
\hline 10. & AZCK & & 83 & 86 & \\
\hline 11. & $\mathrm{AP}$ & & 80 & 87 & \\
\hline 12. & HR & & 83 & 85 & \\
\hline 13. & $\mathrm{AAH}$ & & 79 & 84 & \\
\hline 14. & NIP & & 78 & 84 & \\
\hline 15. & MAG & & 79 & 85 & \\
\hline 16. & MA & & 79 & 86 & \\
\hline 17. & MR & & 80 & 88 & \\
\hline 18. & SAP & & 78 & 84 & \\
\hline 19. & MAPP & & 76 & 86 & \\
\hline 20. & MGRF & & 78 & 86 & \\
\hline
\end{tabular}

Berdasarkan data pada Tabel 2 di atas, dapat digambarkan bahwa nilai hasil belajar siswa dengan kode NS pada siklus I adalah 79 belum memenuhi standar Kriteria Ketuntasan Minimal (KKM) yakni nilai 80, kemudian mengalami peningkatan dengan memperoleh nilai 82. Hal ini menunjukkan terdapat peningkatan angka sebanyak 3 dan sudah melampaui batas KKM, berarti siswa dengan kode NS telah mencapai ketuntasan belajar berdasarkan KKM. Dengan demikian, penerapan model pembelajaran webbed dapat meningkatkan hasil belajar siswa, sehingga menjadi tuntas berdasarkan KKM. Tugas guru selanjutnya adalah melakukan pendalaman materi melalui kegiatan pengayaan untuk memperdalam dan memperluas penguasaan terhadap materi tersebut.

Tabel 3. Deskripsi Peningkatan Hasil Belajar Bahasa Indonesia Siswa Kelas III-C SD Negeri Beroanging Kecamatan Tallo Setelah Menggunakan Model Pembelajaran Webbed

\begin{tabular}{lcccc}
\hline \multirow{2}{*}{ No. } & Deskripsi/Uraian Peningkatan Prestasi & Nilai Hasil Tes Belajar & \multirow{2}{*}{ Ket. } \\
\cline { 3 - 3 } & Belajar Berdasarkan KKM & Siklus 1 & Sikus II &
\end{tabular}




\begin{tabular}{llllll}
\hline & & F & \multicolumn{2}{c}{ F } & $\%$ \\
\hline 1. & Di bawah Nilai KKM (80) & 9 & 45 & - & - \\
2. & Nilai KKM ke atas (80) & 11 & 55 & 20 & 100 \\
\hline & Total & 20 & 100 & 20 & 100 \\
\hline
\end{tabular}

Berdasarkan Tabel 3 di atas, dapat digambarkan bahwa hasil tes pada siklus I dengan subjek penelitian 20 orang menunjukkan hanya 9 orang $(45 \%)$ yang belum tuntas berdasarkan Kriteria Kentuntasan Minimal (KKM) yakni di bawah nilai 80. Sementara subjek penelitian yang telah mencapai nikai KKM (80) ke atas, ada sebanyak 11 orang (55 \%). Berdasarkan data ini, maka guru perlu mendesain atau merancang kembali kegiatan pembelajaran pada siklus II dengan tetap menggunakan atau menerapkan model pembelajaran webbed.

\section{B. Pembahasan Hasil Penelitian}

Model pembelajaran webbed merupakan salah satu model pembelajaran terpadu yang menggunakan tema sebagai dasar pembelajaran. Model pembelajaran ini biasa juga disebut sebagai model jarring laba-laba, yang memadukan multi disiplin ilmu atau berbagai mata pelajaran yang diikat oleh satu tema tertentu. Model pembelajaran ini lebih menekankan pada keterlibatan siswa dalam pembelajaran, sehingga siswa dapat memperoleh pengalaman langsung. Melalui pengalaman langsung itu, akhirnya siswa dapat memahami konsep-konsep yang telah mereka pelajari dan mampu pula menghubungkan dengan konsep lainnya.

Jadi, inti dari model pembelajaran webbed ini adalah model pembelajaran terpadu yang berusaha menggunakan pendekatan tematik dan memadukan multi disiplin ilmu. Berkaitan hal itu, maka dalam pembahasan hasil penelitian ini akan dikemukakan dua hal pentng, yaitu (1) penerapan model model pembelajaran dalam meningkatkan motivasi dan aktivitas belajar Bahasa Indonesia; dan (2) peningkatan hasil belajar membaca Bahasa Indonesia melalui penerapan model pembelajaran Webbed.

Ada beberapa jenis aktivitas belajar, antara lain: (a) aktivitas visual, seperti: membaca, memperhatikan gambar, demonstrasi, percobaan, dsb; (b) aktkvitas berbicara, seperti: menyatakan, merumuskan, bertanya, memberikan saran, mengeluarkan pendapat, mengadakan wawancara, diskusi, interupsi, dsb; (c) aktivitas mendengarkan, seperti: mendengarkan penjelasan, percakapan, diskusi, mendengarkan music, mendengarkan pidato, dsb; (d) aktivitas menulis, seperti: menulis cerita, menulis karangan, menulis laporan, angket, dan menyalin, dsb; (e) aktivitas menggambar atau melukis (drawing), seperti: menggambar, membuat grafik, peta, diagram, pola, dsb; (f) aktivitas motor, seperti: melakukan percobaan, melakukan konstruksi, model, merepasi, bermain, dsb; (g) aktivitas emosional, seperti: menaruh minat, merasa bosan, gembira, bersemangat, bergairah, berani, tenang, gugup.

Aktivitas belajar tentu akan berimplikasi terhadap peningkatan hasil belajar siswa. Namun, peneliti mempertegas bahwa hasil belajar tidak hanya ditentukan oleh aktivitas siswa, tetapi juga aktivitas guru sangat diperlukan untuk merencanakan kegiatan siswa yang bervariasi, sehingga kondisi pembelajaran akan lebih dinamis dan tidak tidak membosankan. Sebagai indikator aktivitas belajar siswa secara individual dalam proses pembelajaran, antara lain: kehadiran di kelas, ketepatan waktu mengumpulkan tugas, kelengkapan buku catatan, menyimak dan memperhatikan penjelasan, menyampaikan pendapat, dsb.

Pernyataan bahwa penggunaan model pembelajaran webbed dapat membangkitkan aktivitas dan motivasi siswa untuk memperluas pemahaman siswa terhadap materi yang disampaikan oleh guru, sehingga mempengaruhi hasil belajar siswa, khususnya membaca, mendapat respon positif dari siswa sebagai responden. Hal ini dibuktikan oleh 55\% responden yang menyatakan sangat setuju dan $45 \%$ yang menyatakan setuju. Hal ini dapat disimpulkan bahwa guru Bahasa Indonesia dalam melaksanakan pembelajaran dengan menggunakan model pembelajaran webbed dapat membangkitkan motivasi siswa untuk memperluas pemahaman mereka terhadap materi pembelajaran, sehingga dapat meningkatkan hasil belajar mereka, khususnya membaca.

\section{Kesimpulan dan Saran}

Berdasarkan uraian yang telah dikemukakan pada bagian sebelumnya, maka dapat ditarik kesimpulan sebagai berikut penerapan model pembelajaran webbed dalam pembelajaran Bahasa Indonesia pada siswa kelas III-C SD Negeri Beroanging Kecamatan Tallo Kota Makassar dapat meningkatkan motivasi dan aktivitas belajar Bahasa Indonesia. Hal ini ditunjukkan oleh respon siswa yang pada umumnya menyatakan respon yang positif (setuju dan sangat setuju) terhadap 10 butir pertanyaan/pernyataan angket, serta tidak ada satu pun respon siswa yang menyatakan respon negatif (tidak setuju dan sangat tidak setuju) terhadap pertanyaan/pernyataan angket tersebut yang berkaitan dengan motivasi dan aktivitas belajar siswa.

Penerapan model pembelajaran webbed dalam pembelajaran bahasa Indonesia pada siswa kelas III-C SD Negeri Beroanging Kecamatan Tallo Kota Makassar dapat meningkatkan hasil belajar Bahasa Indonesia, khususnya membaca. Hal ini ditunjukkan oleh peningkatan hasil belajar siswa pada siklus I yakni perolehan nilai hasil belajar baru mencapai 55\% yang mencapai ketuntasan belajar berdasarkan KKM, kemudian mengalami peningkatan nilai menjadi $100 \%$ pada siklus II.

\section{Daftar Pustaka}

Agus, M. 2015. Kajian Prospektif Kompetensi Profesional Guru Bahasa Indonesia SMA Negeri di Kabuparen Jeneponto Pascasertifikasi. Disertasi. Makassar: Program Pascasarjana UNM Makassar. 
Aini, Nurul dkk. 2013. Model Penemuan Terbimbing (Guided Discovery) pada Pembelajaran IPA Terpadu Tipe Webbed dengan Tema Biopestisida. Jurnal Pendidikan Sain e-Pensa, Volume 01 Nomor 02 Tahun 2013.

Asep Herry Hernawan dan Novi Resmini, Pembelajaran Terpadu, Diretorat Jenderal Pendidikan Islam Departemen Agama RI, Jakarta, 2012

Brown, Douglas H. 2007. Princples of Language Learning and Teaching (Prinsip Pembelajaran dan Pengajaran Bahasa. Edisi Kelima. Diterjemahan oleh Noor Cholis dan Yusri Avianto Pareanom. Jakarta: Kedutaan Besar Amerika Serikat.

Depdikbud. 1996. Pedoman Penulisan Buku Laporan Pendidikan. Jakarta: Depdikbud.

Depdiknas. 2004. Kurikulum 2004 SMP, Pedoman Khusus Pengembangan Sistem Penilaian Berbasis Kompetensi Mata Pelajaran Sains. Jakarta: Depdiknas.

Ghozali, Imam. (2015). Aplikasi Analisis Multivariate dengan Program IBM SPSS 23. Semarang : Badan Penerbit Universitas Diponegoro.

Isrok'atun, Amelia Rosmala.2018. Model-Model Pembelajaran Matematika. Jakarta: BumiAksara.

Jainuddin, J., \& Sirajuddin, S. (2020). Pengaruh Minat dan Kedisiplinan Siswa dengan Gaya Kognitif Field Indefendent terhadap Hasil Belajar Matematika Siswa SMK Farmasi Yamasi Makassar. Delta-Pi: Jurnal Matematika dan Pendidikan Matematika, 9(2).

Santoso, Singgih. 2007. Statistik Deskriptif: Konsep dan Aplikasi dengan Microsoft Exel dan SPSS. Yogyakarta: ANDI

Widoyoko, S. Eko Putro. 2019. Evaluasi Program Pembelajaran. Yogyakarta: Pustaka Pelajar. 